\title{
ONION SEEDLING PRODUCTION IN STYROFOAM TRAYS UNDER CONTROLLED ENVIRONMENT, AS SUMMER-PLANTED ONIONS
}

\author{
Maria Cristina Veiga De Vincenzo ${ }^{1 *}$; João Tessarioli Neto \\ ${ }^{1}$ Depto. de Produção Vegetal - USP/ESALQ, C.P. 9 - CEP: 13418-900 - Piracicaba, SP. \\ *Corresponding author <crisvincenzo@hotmail.com>
}

\begin{abstract}
Summer-planted onion ( Allium cepa L.) can increase grower profits, but the production of seedlings for transplant is difficult. This experiment was carried out in Piracicaba, SP, Brazil, with the objective of studying the behavior of the short-day onion hybrid Mercedes, in its initial stage, under controlled greenhouse environment, as summer-planted onions. Four formulated substrates, two different numbers of plants per cell were tested, and 288-cell styrofoam trays used. Trials were set up in split-plot design $(n=3)$. Substrate and number of plants per cell represented main plots, and $\mathrm{N}$ application ( 2 and 3 times a week) the subplots. The number of three plants per cell decrease the earlier onset of bulbing and increase plant height; substrates did not show differences; and the $\mathrm{N}$ application 3 times a week increased plant height and leaf dry weight, but did not result in earlier onset of bulbing.
\end{abstract}

Key words: Allium cepa, tray, greenhouse, short-day onion, seedling

\section{PLANTAS DE CEBOLA PRODUZIDAS EM BANDEJAS SOB CULTIVO PROTEGIDO, NO VERÃO}

\begin{abstract}
RESUMO: Uma das dificuldades do cultivo do verão da cebola ( Allium cepaL.), que permite maior lucro pois esta é a época de entressafra, é a produção de plantas para o transplante. Com o objetivo de verificar o comportamento na fase de muda do híbrido Mercedes, sob cultivo protegido como cultura de verão, o experimento foi instalado em estufa, em Piracicaba, SP com bandejas de isopor de 288 células. Foram testados quatro substratos. e dois números de plantas por células ( 3 e 4 plantas/célula), sendo sub-plot a suplementação mineral com nitrogênio 2 e 3 vezes por semana com nitrato de cálcio + nitrato de potássio. 0 delineamento experimental foi inteiramente casualizado, com fatorial $4 \times 2 \mathrm{em}$ parcelas subdivididas, e três repetições. A densidade de três plantas por célula apresentou menor taxa de bulbificação precoce e maior altura da planta; não houve diferença quanto aos substratos e que a aplicação de nitrogênio três vezes por semana apresentou os maiores valores de altura da planta e peso da matéria seca da parte aérea, não apresentando bulbificação precoce das plantas.
\end{abstract}

Palavras-chave: Allium cepa, cebola, bandeja, cultivo de verão, muda

\section{INTRODUCTION}

Onion is one of the vegetables of highest importance in Brazil, only behind the tomato and the potato. Brazil is ranked tenth among onion producers, with a total yield of $912,000 \mathrm{t}$, a productivity of $13 \mathrm{t} \mathrm{ha}^{-1}$, and having a 70,000 hectare planted area. The State of São Paulo is responsible for $28 \%$ of this production, with a total of $245,290 \mathrm{t}$ and $14 \mathrm{t} \mathrm{ha}^{-1}$ productivity (Kassab, 1994; Cardoso \& Costa, 1999; Fnp Consultoria \& Comércio, 1999).

The Brazilian market is supplied with onions of the southern region from January to April, of the northeastern region from July to October, and of the State of São Paulo from July to November. Onions are also imported from Argentina from March to June (FNP Consultoria \& Comércio, 1999). The between-harvest period corresponds to the short-day photoperiod and low temperatures. Thus, from February to July onion reaches highest prices (Camargo, 1995; Resende et al., 1996), making summer-planted onion into a way to increase growers profits (Camargo Filho \& Mazzei, 1994; Azevedo Jr, 1990).

The onion crop in the majority of the Brazilian states is based on seedbed plant production, with subsequent transplant to the field (Guimarães \& Dittrich, 1997). Seedlings are transplanted with naked root, without substrate for protection being very sensible to the environment conditions, besides having damages that facilitate infections by pathogenic agents (Souza \& Ferreira, 1997; Cardoso \& Costa, 1999).

Onion growers are looking for an alternative planting method that is easier to control. A conversion is occurring from plants grown in the field after transplanting with naked root to the production of plants in trays within greenhouses. The transplant of these plants is feasible and safer (Herison et al., 1993).

The local production of plants in greenhouse, can be an option for the onion grower (Herison et al., 1993). The technique to obtain onion seedling through the use of multicellular trays leads to a practical and economic method that improved onion production 
(Weerasinghe \& Fordham, 1994; Tessarioli Neto, 1995; Modolo, 1998).

The use of the tray system has provided increases in the number of crops grown from transplants, due to the presence of substrates that protect the root from the transplant stress. Without this stress the cycle of the crop in the field (after transplant) can be reduced and the crop is more profitable to the grower (Minami, 1995).

Onion plants with more than four leaves, $0.3 \mathrm{~g}$ dry weight and/or $2.5 \mathrm{~mm}$ pseudostem diameter at the time of transplant, can be classified as small seedling. These small plants answer quicker to the photoperiod than the others and initiate bulbing earlier (Mettananda \& Fordham, 1999). To onset bulbing the onion plant needs adequate photoperiod and temperature (Currah \& Proctor, 1990; Barbedo et al., 1991; Brewster, 1994; Kassab, 1994; Cardoso, 1997). The formation of bulbs is a reply to the long days (Whatley \& Whatley, 1982; Wilkins, 1985). When the photoperiod is adequate the onset of bulbing and the rate to full development depend on secondary factors, such as temperature, nutrient availability, soil moisture and stand density (Sobrino Illescas \& Sobrino Vesperinas, 1992; Brewster, 1994; Minami \& Tessarioli Neto, 1994; Paiva, 1994; Blacksmith, 1999; Mettananda \& Fordham, 1999). If the environment is adequate the process will occur even in the phase of seedling production, followed by the death of the plant and the dormancy of the little bulb. This is called "early onset of bulbing", and is undesirable in the seedling production phase.

Nitrogen fertilization slows the formation of bulbs. The onset of bulbing is antecipated by nitrogen deficiency and delayed by its excess (Sonnenberg, 1981; Cardoso, 1997). High nitrogen levels result in an increment of the aerial part and poor bulb development (Felippe, 1986; Kassab, 1994; Cardoso, 1997), causing delay and reduction in the onset of bulbing (Della Vecchia, 1974).

Under field conditions, the microenvironment to which each plant is individually exposed, is influenced by the neighbor plants (Cardoso, 1997). Competition among plants increases with the development of the crop, for both light and nutrients, modifying the process of bulbing. In plants under ideal conditions, this process is accelerated with high density of plants, and the precocious onset of bulbing is quicker (Rabinovick \& Brewster, 1990; Mascarenhas, 1993). The competition among plants during propagation can reduce the size of the seedlings and affect their development after transplant (Weerasinghe \& Fordham, 1994).

The summer-planting, of onion presents a number difficulties, the greatest being the production of seedlings for the transplant. During the summer, high temperature and high rainfall coincide, and this makes the management difficult and leads to an excess of water in the root system. These factors may promote the development of pathogens that cause root diseases and weed, encroachment during a phase in which the onion plant is less competitive.
The objective of this research was to study the behavior of the short-day onion hybrid Mercedes in its initial stage, under controlled environment, as summerplanted onions.

\section{MATERIAL AND METHODS}

The experiment was carried out in Piracicaba, SP, Brazil, with the production of seedlings in a wooden dome-shaped greenhouse, $20 \mathrm{~m}$ long, $5 \mathrm{~m}$ wide and 3 $\mathrm{m}$ high, covered with a plastic screen of $50 \%$ shade. The short-day hybrid Mercedes is precocious and low demanding, with a life cycle of 125 to 130 days, and a critical photoperiod of 10 to 12 hours (Topseed, s.d.)

For the production of the seedlings 288-cell styrofoam trays were used. Each of the square-shaped cells have a volume of $9.7 \mathrm{~cm}^{3}$ and are distributed in a $12 \times 24$ arrangement. Sowing (five to six seeds per cell) occurred in 1999/Feb/05. After sowing trays were watered. Irrigation was controlled automatically through sensors during the experimental period. The temperature inside the greenhouse ranged between 20 and $24^{\circ} \mathrm{C}$ from 18 to $8 \mathrm{~h}$. Between 24 and $30^{\circ} \mathrm{C}$ from 8 to $18 \mathrm{~h}$. The higher temperatures (26 to $30^{\circ} \mathrm{C}$ ) occurred from 12 to 14 o' clock. The relative humidity varied between 85 and $98 \%$ from 18 to $8 \mathrm{~h}$; and from 85 to $56 \%$ from 8 to $18 \mathrm{~h}$. The lowest relative humidity (56 to $60 \%$ ) occurred from 12 to $14 \mathrm{~h}$.

Germination initiated six days after the sowing (1999/Feb/11) and the excess of the plants was thinned seven to eight days after its emergency, keeping the required number of plants per cell. After this, the normal practices of the onion crop were initiated.

Four types of substrate, two numbers of plants per cell; and $\mathrm{N}$ application, were the treatments. The substrates were: S1 - Plantmax HT, commercial product, mixture of pine bark, processed peat and vermiculite, with NPK fertilization (1.5: 1.0: 0.5); S2 - experimental product, of the same composition as S1, with another NPK fertilization - the PG Mix by Hydro (1.5: 1.0: 2.0); S3 Test CM, experimental product, mixture of pine bark, vermiculite and perlite, with NPK fertilization (1.5: 1.0: 0.5) and S4 - experimental product, of the same composition as Test CM, with another NPK fertilization - the PG Mix by Hydro (1.5: 1.0: 2.0).

The numbers of plants after thinning ( 17 days after sowing) were: M1 (three plants per cell) and M2 (four plants per cell).

$\mathrm{N}$ application (calcium nitrate and potassium nitrate) started 4 days after thinning, and consisted of: N1 (2 times a week (Monday and Thursday)) and N2 (3 times a week (Monday, Wednesday and Friday)). The rates were: $1.5 \mathrm{~g}$ calcium nitrate $\mathrm{L}^{-1}$ of water $(15.5-0-$ $0)+1.0 \mathrm{~g}$ potassium nitrate $\mathrm{L}^{-1}$ of water $(13-0-44)$; $250 \mathrm{~mL}$ solution were applied per tray.

Each tray was a plot, divided in two sub-plots according $\mathrm{N}$ frequency. Each sub-plot had 70 cells, 
leaving four rows without substrates to split the sub-plots. The trial was set up in a split-plot design $(n=3)$. Substrates (S1, S2, S3 and S4) and number of plants per cell (M1 and M2) were main plot, and N frequency (N1 and N2) the sub plot, making a total of 24 trays.

The evaluations for the analysis of plant growth were carried out 16, 21 and 26 days after emergence. On those sampling occasions, four cells per sub-plot were removed, taken to the laboratory and plants were washed to completely remove the adherent substrate from roots.

The following responses were evaluated: Pseudostem diameter; Plant height; Leaf dry weight, considering all plants of one cell, in a $65^{\circ} \mathrm{C}$ oven.

The dates of plant evaluation after emergence (DAE), were: 27 Feb (16 DAE), Mar/04 (21 DAE) and 9 mar (26 DAE).

\section{RESULTS AND DISCUSSION}

\section{Pseudostem diameter}

The density of four plants per cell resulting in larger pseudostem diameters than that of 3 plants per cell, in the first evaluation at Feb/27 (3.1 and $2.8 \mathrm{~mm}$, respectively) (Table 1 ) .

The higher density increases the diameter of the pseudostem in the first evaluation, due to competition for $\mathrm{N}$ and to the "temperature photoperiod" interaction which hastens bulbing onset in seedlings; however in the final evaluation (Mar/09) the ideal time to transplant seedlings, there was no difference between pseudosterms, consisting of $3.7 \mathrm{~mm}$ for both densities.

McGeary (1985), Mondal et al. (1986), Brewster (1990) and Weerasinghe \& Fordham (1994) showed that lower sowing densities resulted in increased crop cycle and production of larger bulbs. In our case the results were the same for densities of sowing.

The larger the number of plants per cell, the lower the weight and the diameter of the bulbs, possibly due to increased competition among plants (Cardoso, 1999). Hartridge-Esh \& Bennett (1980); McGeary (1985); Mondal et al. (1986); Brewster (1990), Brewster et al. (1991), also reported smaller bulb size in response to greater number of plants per cell.

Stand density in the field is one of the most important factors that affect growth and development of onions, impacting commercial productivity (Weerasinghe \& Fordham, 1994). In relation to transplanted seedlings, the competition among plants for light at high plant densities can modify bulb development and antecipate maturity and harvest (Mondal et al., 1986). Considering this, it is better to transplant seedlings of a cell with three plants, which will be able to produce larger bulbs, than transplant from a cell with four plants.

Weerasinghe \& Fordham (1994), studying the number of onion plants per cell (one to six) to produce plants for transplant, showed that the greater the number of plants per cell, the smaller the size of the bulbs produced. They concluded that the most important competitive effect was nitrogen, affecting the size of the bulb more than the crop cycle. In the present study $\mathrm{N}$ application (wo or three times a week) did not affect pseudostem diameter, the same occurring for numerical values of the pseudostem diameter.

\section{Plant height}

In the second evaluation Mar./04), plants were taller at three plants per cell, having $(13.0 \mathrm{~cm}$, versus 11.7 $\mathrm{cm}$ for four plants per cell) (Table 2). In the third evaluation (Mar./09) plant heights were the same across densities $(16.9 \mathrm{~cm}$ and $15.5 \mathrm{~cm}$ for three and four plants per cell, respectively). Several authors (Mascarenhas. 1993; Kassab. 1994; Minami \& Tessarioli Neto 1994; Blanco et al., 1997) consider a seedling of $15 \mathrm{~cm}$ ideal for transplanting.

The highest mean plant height in the third evaluation (interaction between the factors sowing density and $\mathrm{N}$ application, Table 3), was for three plants per cell and three weekly $\mathrm{N}$ applications, $(18.2 \mathrm{~cm})$. With this density and the most frequent $\mathrm{N}$ application rate, the effect of competition between plants in the same cell was attenuated, and nitrogen also stimulated the development of the plants.

It is possible to produce onion seedlings of different sizes at the same age with the use of different

Table 1 - Pseudostem diameter of plants grown in different substrates, having different number of plants per cell and different N applications, evaluated in 1999/ Feb/27; Piracicaba - SP.

\begin{tabular}{llllll}
\hline \multirow{2}{*}{ Plants per cell } & \multicolumn{4}{c}{ Substrate } & \multirow{2}{*}{ Mean pseudosterm } \\
\cline { 2 - 5 } & $\mathrm{S}^{2}$ & S2 & S3 & S4 & \\
\hline 3 & 2.9 & 2.6 & 2.7 & 2.9 & $2.8^{1} \mathrm{~b}$ \\
4 & 3.1 & 3.1 & 3.2 & 2.9 & $3.1 \mathrm{a}$ \\
\hline $\mathrm{CV}$ & & & &
\end{tabular}

$\mathrm{CV}(\mathrm{a})=15.2 \% \quad \mathrm{LSD}=0.3 \quad \mathrm{CV}(\mathrm{b})=18.6 \%$

${ }^{1}$ Significant differences for the confidence level of $95 \%$ are indicated by different letters (Tukey Test).

${ }^{2} \mathrm{~S} 1$ - Plantmax HT; S2 - experimental product (same composition of S1, another fertilization PG Mix by Hydro); S3 - Test CM (experimental product); S4 - experimental product (same composition of S3, another fertilization PG Mix by Hydro).

Table 2 - Plant height for from substrates, two densites of plants per cell and $\mathrm{N}$ applications, evaluated in 1999/Mar/04; Piracicaba - SP.

\begin{tabular}{|c|c|c|c|c|c|}
\hline \multirow{2}{*}{$\begin{array}{l}\text { Plants per } \\
\text { cell }\end{array}$} & \multicolumn{4}{|c|}{ Substrate } & \multirow{2}{*}{ Mean pseudosterm } \\
\hline & $\mathrm{S} 1^{2}$ & S2 & S3 & S4 & \\
\hline & & & & & ----- mm ----- \\
\hline 3 & 12.4 & 12.3 & 14.4 & 13.0 & $13.0^{1} \mathrm{a}$ \\
\hline 4 & 12.6 & 12.1 & 11.3 & 10.6 & $11.7 b$ \\
\hline
\end{tabular}

${ }^{1}$ Differences for the confidence level of $95 \%$ are indicated by different letters (Tukey Test).

${ }^{2} \mathrm{~S} 1$ - Plantmax HT; S2 - experimental product (same composition of S1, another fertilization PG Mix by Hydro); S3 - Test CM (experimental product); $\mathrm{S} 4$ - experimental product (same composition of $\mathrm{S} 3$, another fertilization PG Mix by Hydro). 
sowing densities and shade, under tropical conditions, under which the number of plants per cell affects the size of the seedlings and the time of transplanting (Weerasinghe \& Fordham, 1994). The growth of the plants for low densities was faster in relation to high density.

Plant heights were different in the second evaluation due to $\mathrm{N}$ application, the taller plants with three weekly applications, and three plants per cell, being 18.2 and $15.6 \mathrm{~cm}$ (three and two weekly applications respectively). The use of fertilizers increased plant growth until a maximum of about $50 \%$ above the control (Brewster et al., 1991).

\section{Leaf dry weight}

On the second evaluation, (Mar./04) (Table 2) the lower sowing density (three plants per cell) led to taller plants as compared to the density of four plants per cell (13.0 and $11.7 \mathrm{~cm}$, respectively). This is reflected in leaf dry weight (Table 4), with the density of three plants per cell $(0.26 \mathrm{~g})$ having a greater weight than the density of four plants per cell $(0.23 \mathrm{~g})$, since the greater the leaf the larger its dry weight.

For Hibiscus esculentus the highest means occurred in plants coming from trays with greater cellular volume (Modolo, 1999), or with less densities of sowing. This also reflects what was argued for plant height in relation to sowing density.

Leaf dry weight (Tables 5 and 6), in the second and third evaluations were greater for three weekly $\mathrm{N}$ applications ( $0.26 \mathrm{~g}$ and $0.39 \mathrm{~g}$, respectively).

Table 3 - Pseudostem diameter of plants grown in substrates, number of plants per cell and $\mathrm{N}$ applications, evaluated in 1999/Mar/09; Piracicaba - SP.

\begin{tabular}{lcc}
\hline \multirow{2}{*}{ Plants per cell } & \multicolumn{2}{c}{$\mathrm{N}$ applications per week } \\
\cline { 2 - 3 } 3 & $2 \mathrm{x}$ & $3 \mathrm{x}$ \\
\hline 3 & $15.6^{1} \mathrm{Ab}$ & $18.2 \mathrm{Aa}$ \\
4 & $15.2 \mathrm{Aa}$ & $15.8 \mathrm{Ba}$ \\
\hline
\end{tabular}

$\mathrm{CV}(\mathrm{a})=19.1 \% \mathrm{LSD} 1=2.1$ (plants per cell comparison, column)

$\mathrm{CV}(\mathrm{b})=9.4 \% \quad$ LSD2 $=1.3$ ( $\mathrm{N}$ application comparison, line)

'Differences for the confidence level of $95 \%$ are indicated by different letters (Tukey Test).

Table 4 - Leaf dry weight for substrates, number of plants per cell and N applications, evaluated in 1999/Mar/04 Piracicaba-SP.

\begin{tabular}{|c|c|c|c|c|c|}
\hline \multirow{2}{*}{ Plants per cell } & \multicolumn{4}{|c|}{ Substrate } & \multirow{2}{*}{ Mean dry weight } \\
\hline & $\mathrm{S} 1^{2}$ & $\mathrm{~S} 2$ & S3 & S4 & \\
\hline & & & & & ----- g ----- \\
\hline 3 & 0.25 & 0.24 & 0.29 & 0.26 & $0.26^{1} \mathrm{a}$ \\
\hline 4 & 0.25 & 0.24 & 0.22 & 0.20 & $0.23 \mathrm{~b}$ \\
\hline \multicolumn{6}{|c|}{$\begin{array}{l}\mathrm{CV}(\mathrm{a})=17.40 \% \quad \mathrm{LSD}=0.03 \quad \mathrm{CV}(\mathrm{b})=13.31 \% \\
\text { 'Differences for the confidence level of } 95 \% \text { are indicated by different } \\
\text { letters (Tukey Test). } \\
\text { 'S1 - Plantmax HT; S2 - experimental product (same composition of } \\
\text { S1, another fertilization PG Mix by Hydro); S3 - Test CM (experimental } \\
\text { product); } 54 \text { - experimental product (same composition of S3, another } \\
\text { fertilization PG Mix by Hydro). }\end{array}$} \\
\hline
\end{tabular}

In the third evaluation (Mar./09) an interaction occurred between density of sowing and $\mathrm{N}$ application (Table 6), three weekly $\mathrm{N}$ applications and three plants per cell presenting the largest leaf dry weight $(0.39 \mathrm{~g})$. Therefore $\mathrm{N}$ application three times a week seems to have stimulated vegetative growth, reflected in an increase of the leaf dry weight.

Barros (1997), evaluated the yield and tomatoes and cucumber plants in different containers and verified that trays with greater cellular volume lead to greater foliar area, leaf dry weight and root system. Weerasinghe \& Fordham (1994) and Mettananda \& Fordham (1999), worked with onion plant production, and observed that the number of leaves, leaf dry weight and the plant size significantly decreased with the increase of the density of sowing (1, 2, 4 and 6 plants per cell).

Boff \& Debarba (1999) studying different densities of onion sowing reported that the number of plants per cell affected significantly plant height and the root fresh weight. These measurements decreased linearly when the number of plants per cell increased from 1 to 3 . The number of plants for transplant was greater for the lower density of sowing, as well as plant mean weight, which was greater for low densities, indicating that greater densities affect the development of the seedlings, reducing the exploitation index during the occasion of the transplant.

Table 5 - Leaf dry weight for substrates, number of plants per cell and N applications, evaluated in 1999/Mar/04; Piracicaba-SP.

\begin{tabular}{|c|c|c|c|c|c|}
\hline \multirow{2}{*}{$\begin{array}{l}\mathrm{N} \text { application } \\
\text { per week }\end{array}$} & \multicolumn{4}{|c|}{ Substrate } & \multirow{2}{*}{ Mean dry weight } \\
\hline & $\mathrm{S} 1^{2}$ & S2 & S3 & S4 & \\
\hline & & & & & ---- g ----- \\
\hline $2 x$ & 0.25 & 0.23 & 0.23 & 0.22 & $0.23^{1} \mathrm{~b}$ \\
\hline $3 x$ & 0.25 & 0.25 & 0.28 & 0.25 & $0.26 \mathrm{a}$ \\
\hline \multicolumn{6}{|c|}{$\begin{array}{l}\mathrm{CV}(\mathrm{a})=17.40 \% \quad \mathrm{LSD}=0.02 \quad \mathrm{CV}(\mathrm{b})=13.31 \% \\
\text { 'Differences for the confidence level of } 95 \% \text { are indicated by different } \\
\text { letters (Tukey Test). } \\
\text { 'S1 - Plantmax HT; S2 - experimental product (same composition of } \\
\mathrm{S} 1 \text {, another fertilization PG Mix by Hydro); S3 - Test CM (experimental } \\
\text { product); S4 - experimental product (same composition of S3, another } \\
\text { fertilization PG Mix by Hydro). }\end{array}$} \\
\hline
\end{tabular}

Table 6 - Leaf dry weight for the substrates, number of plants per cell and $\mathrm{N}$ applications. Interation between number of plants per cell and $\mathrm{N}$ applications, evaluated in 1999/Mar/09; Piracicaba-SP.

\begin{tabular}{|c|c|c|}
\hline \multirow{2}{*}{ Plants per cell } & \multicolumn{2}{|c|}{$\mathrm{N}$ applications per week } \\
\hline & $2 x$ & $3 x$ \\
\hline \multicolumn{3}{|l|}{----- g ---- } \\
\hline 3 & $0.33^{1} \mathrm{Ab}$ & $0.39 \mathrm{Aa}$ \\
\hline 4 & $0.32 \mathrm{Aa}$ & $0.33 \mathrm{Ba}$ \\
\hline
\end{tabular}




\section{CONCLUSION}

It is possible to produce onion seedlings in trays under controlled environment in the summer, and that three plants per cell prevent the early onset of bulbing and promote an increase in plant height. $\mathrm{N}$ application three times a week increases plant height and leaf dry weight, but does not result in earlier onset of bulbing. Substrates did not present differences.

\section{REFERENCES}

AZEVEDO JR., P.R. Seleção de cultivares de cebola ( Allium cepa L.) visando bulbificação no período de março/abril em Viçosa, MG. Viçosa, 1990 45p. Dissertação (Mestrado) - Universidade Federal de Viçosa.

BARBEDO, C.J.; OLIVEIRA, D.L.; RODRIGUES, L.A.S. Influência de épocas de plantio e diâmetros dos bulbinhos para plantio, no cultivo de cebola em Bandeirantes - PR. Poliagro, v.10, p.79-85, 1991

BARROS, S.B.M. Avaliação de diferentes recipientes na produção de plants de tomate (Lycopersicun esculentum Mill.) e pepino (Cucumis sativus L.). Piracicaba, 1997. 70p. Dissertação (Mestrado) - Escola Superior de Agricultura "Luiz de Queiroz", Universidade de São Paulo.

BLANCO, M.C.S.G.; GROPPO. G.A.; TESSARIOLI NETO. J. Cebola (Allium cepa L.) In: COORDENADORIA DE ASSISTÊNCIA TÉCNICA E INTEGRAL. Manual técnico das culturas: olerícolas, medicinais e ornamentais. 2.ed. Campinas, 1997. v.2, n.8, p.37-43.

BOFF, P.; DEBARBA, J.F. Tombamento e vigor de plants de cebola em função de diferentes profundidades e densidades de semeadura. Horticultura Brasileira, v.17, p.15-19, 1999.

BREWSTER, J.L. Physiology of crop growth and bulbing. In : RABINOWITH, H.D.; BREWSTER, J.L. (Ed.) Onions and allied crops: botany, physiology and genetics. Boca Raton: CRC Press, 1990. v.1, p.53-88.

BREWSTER, J.L. Onions and other vegetable alliums. Cambridge: CAB International, 1994. 236p. (Crop Production Science in Horticulture).

BREWSTER, J.L.; ROWSE, H.R.; BOSCH, A.D. The effects of sub-seed placements of liquid $\mathrm{N}$ and Paulo fertilizer on the growth and development of bulb onions over a range of plant densities using primed and non-primed seed. Journal of Horticultural Science, v.66, 551-557, 1991

CAMARGO FILHO, W.P.; MAZZEI, A.R. Hortaliças prioritárias no planejamento da produção orientada: estacionalidade da produção e dos preços. Informações Econômicas, v.24, p.9-54, 1994

CAMARGO FILHO, W.P. Cebolicultura nacional e Mercosul. In: CONGRESSO BRASILEIRO DE OLERICULTURA, 35., Foz de Iguaçu, 1995. Resumos. /Horticultura Brasileira, v.13, p.73, 1995./

CARDOSO, A.I.I.; COSTA, C.P. da. Produção de bulbinhos de cebola em bandejas de isopor. Scientia Agricola, v.56, p.969-974, 1999

CARDOSO, A.I.I. Seleção de cebola (Allium cepa L.) para bulbificação maturidade no sistema de cultivo de bulbinhos de "ciclo curto". Piracicaba, 1997. 105p. Tese (Doutorado) - Escola Superior de Agricultura "Luiz de Queiroz", Universidade de São Paulo.

CURRAH, L.; PROCTOR, F.J. Onion in tropical regions. Kent: Natural Resources Institute, 1990. 232p. (Bulletin, 35)

DELLA VECCHIA, P.T. Produção de sementes de cebola. Piracicaba: CALQ, 1974. 100p.

FELIPPE, G.M. Fotomorfogênese. In : FERRI, M.G. (Coord.) Fisiologia vegetal. 2.ed. São Paulo: EPU, 1986. v.2, cap.9, p.231-280.

FERREIRA, M.D. Qualidade de bulbos de cebola em função de diferentes tratamentos pré-colheita. Piracicaba, 1999. 90p. Tese (Doutorado) - Escola Superior de Agricultura Luiz de Queiroz, Universidade de São Paulo.
FNP CONSULTORIA E COMÉRCIO. AGRIANUAL: anuário da agricultura brasileira. São Paulo, 1999. 521p.

GUIMARÃES, D.R.; DITTRICH, L.T.; DITTRICH, R.C. Viabilidade técnica da semeadura direta para a cultura da cebola. Agropecuária Catarinense, v.10, p.57-61, 1997

HARTRIDGE-ESH, K.A.; BENNETT, J.P. Effects of seed weight, plant density and spacing on yield responses of onions. Journal of Horticultural Science, v.55, p.247-252, 1980.

HERISON, C.; MASABNI, J.G.; ZANDSTRA, B.H. Increasing seedling density, age and nitrogen fertilization increases onion yield. HortScience, v.28 p.23-25, 1993.

KASSAB, A L. Cebola: do túmulo dos faraós às exigentes mesas modernas. 2.ed. São Paulo: Editora Ícone, 1994. 114p. (Coleção Brasil Agrícola) MASCARENHAS, M.H.T. Cebola. Informe Agropecuário, v.14, p.69-73, 1993

McGEARY, D.J. de. The effects of plant density of the shape, size, uniformity, soluble solids content and yield of onions suitable for pickling, Journal of Horticultural Science, v.60, p.83-87, 1985.

METTANANDA, K.A.; FORDHAM, R. The effects of plant size and leaf number on the bulbing of tropical short-day onion (Allium cepa L.) under controllee environments in the United Kingdom and tropical field conditions in $\mathrm{Sr}$ Lanka, Journal of Horticultural Science \& Biotechnology, v.74, p.622631, 1999.

MINAMI, K. Produção de plants de alta qualidade em horticultura. São Paulo: Fundação Salim Farah Maluf, 1995. 129 p.

MINAMI, K.; TESSARIOLI NETO, J. Cultura da cebola. Piracicaba: SEBRAE; ESALQ, 1994. 46p. (Cursos agrozootécnicos)

MODOLO, V.A. Avaliação de recipientes e substratos para a produção de plants de quiabeiro (Abelmoschus esculentus (L.) Moench.). Piracicaba, 1998. 53p. Dissertação (Mestrado) - Escola Superior de Agricultura Luiz de Queiroz, Universidade de São Paulo.

MONDAL, M.F.; BREWSTER, J.L; MORRIS, G.E.L.; BUTLER, H.A Bulb development in onion (Allium cepa L.) I. Effects of plant density and sowing date in field conditions. Annals of Botany, v.58, p.187-195, 1986.

PAIVA, W.O. de; NODA, H. Cultivo experimental de cebola no Amazonas, Horticultura Brasileira, v.2, p.149-153, 1994.

RABINOVICH, H.D.; BREWSTER, J.L. Onion and allied crops. Boca Raton : CRC Press, 1990. 273p.

RESENDE, G.M. de; GOULART, A.C.P.; SILVA, R.A. Características de produção de cultivares de cebola de cultivo de verão. Horticultura Brasileira, v.14, p.151-154, 1996.

SOBRINO ILLESCAS, E.; SOBRINO VESPERINAS, E. Tratado de horticultura herbácea: hortalizas de legumbre, tallo, bulbo y tuberosas. Barcelona: Biblioteca Agricola Aedos, 1992. v.2, 333p.

SONNENBERG, P.E. Olericultura especial: cultura de alface, alho, cebola, cenoura, batata e tomate. 3.ed. Goiânia: Universidade Federal de Goiás, 1981. 173p. (Curso de Agronomia)

SOUZA, R.J.; FERREIRA, A.A. Produção de plants de hortaliças em bandejas: economia de sementes e defensivos. A Lavoura, v.100, p.19-21, 1997.

TESSARIOLI NETO, J. Recipientes, embalagens e acondicionamentos de plants e hortaliças. In: MINAMI,K. Produção de plants de alta qualidade em horticultura. São Paulo: Fundação Salim Farah Maluf, 1995. p.5964.

TOPSEED SEMENTES LTDA. Mercedes. Petrópolis, s.d. 1v.

WEERASINGHE, S.S.; FORDHAM, R. The effects of plant density on onions established from multiseeded transplants. Acta Horticulturae, n.371, p.97104, 1994.

WHATLEY, J.M.; WHATLEY, F.R. A luz e a vida das Plantas. São Paulo: EPU; EDUSP, 1982. 101p. (Temas de Biologia, 30)

WILKINS, M.B. (Ed.) Advanced plant physiology. Marsfield: Pitman Publishung, 1985. 514p.

Received February 8, 2001 